\title{
Diversity and Monthly Fluctuations in Density of Zooplanktons with Special Reference to Tamadalge Perenial Tank, Kolhapur (M. S.), India
}

\author{
S. A. Manjare \\ Department of Zoology, Jaysingpur College, Jaysingpur
}

\begin{abstract}
The present investigation was made to study the diversity and monthly variation in density of zooplanktons at Tamadalge perennial tank of Kolhapur district, Maharashtra, India. Present investigation highlighted that 16 species of zooplankton belonging to 4 groups namely, rotifers, cladocers, copepodes and ostracods. Qualitatively and quanitatively, coepodes were observed as dominant group. All four groups have shown monthly variation during both the years and noted lower during monsoon season while higher during summer season. Rotifers ad Cladoceran groups were exhibited their presence throughout the study period. Based on the present investigation it can be concluded that the water from the reservoir is tending towards pollution as pollution tollerent copepode group was dominanting during both the years.
\end{abstract}

Keywords: Zooplankton, diversity, monthly variation, density, Tamadalge reservoir, partially polluted

\section{Introduction}

According to Rao (2005), zooplankton incorporates primary and partly secondary micro faunal consumer operative system. This serves the functional biomass on the detritus spectrum in water. Jeje and Fernando (1986) emphasize that the distribution of zooplankton is influenced by interaction of biotic and abiotic factors such as temperature, dissolved oxygen, salinity and other physico-chemical characteristics. Purushothama et al. (2011) highlights that zooplankton are sensitive to their environment, variation in zooplankton density can indicate a subtle environmental change. Most of the civilization in India settled to periphery of major rivers and remaining near small rivers and wetlands. Since pollution status at the wetlands are considerably alarming and influencing diversity of biotic factors in and around these wetlands. Zooplankton are an important biotic entity which are directly affected by anthropogenic activities (Patil et al. 2015).

\section{Materials and Methods}

\section{Study Area}

It is situated about $6 \mathrm{~km}$ west to Hatkanangle covering maximum area of about 121 ha.(300 acre) with average water spread area of about 6.5 ha. It was constructed in 1976 by Kolhapur Patbandhare mandal, Laghu Jalsinchan Vibhag, Kolhapur. The local and other fishermen community primarily uses it as a source of drinking water and secondarily for fish production. It is auctioned on lease for the period of 3-5 years by Grampanchyat Tamdalge for fishery purpose. During the period of investigation Tamdalge tank was free of aquatic vegetation. It has only two inlets (sources) of rain water, both from hilly region. It has no other source of water. Thus exhibit more fluctuations in its water level. It was characterized by more anthropogenic activities and silt bottom and huge algal bloom throughout year. Molluscan fauna is absent in this tank (Manjare, 2015).

\section{Zooplankton Analysis}

The present study was carried out from January 2011 to December 2012. The water samples were collected by filtering 100 liters of water monthly through plankton net made up of bolting silk with pore size of $50 \mu$ for the analysis of plankton and brought to laboratory and $4 \%$ formalin was added. Qualitative and quantitative analysis of zooplankton was carried out in the laboratory by using Sedgwick- Rafter cell counting chamber as suggested by Adoni et al. (1985) and Trivedy and Goel (1984). Identification of plankton were carried out by using keys by Needham and Needham (1962), Adoni et al. (1985), Michael (1984) and Tonapi (1980).

\section{Results and Discussion}

During the tenure of study from January 2011 to December 2012, 16 species were identified. These species are belonging to 4 major groups i.e. Rotifera, Copepoda, Cladocera and Ostracoda. Among all the four major groups 4 species of Rotifers (Brachionus calciflorus, Brachionus quadrientata, Keretella tropica, and Tricholera longiseta), 5 species of copepods (Encyclop sprinophorus, Mesocyclops luckart, Mesocyclops sp., Nauplius sp. and Paracyclops sp.), 4 species of Cladocers (Daphnia carinata, Monia brachiate, Macrotrix laticornis and Cyprissub globusa) and 2 species of Ostracodes (Cypris sp. and Stenocypris sp.) were recorded during this study. The total number of zooplankton were fluctuated between $202 \mathrm{org} / 1$ and $2478 \mathrm{Org} / \mathrm{l}$ during 2011 and $231 \mathrm{Org} / 1$ to $2868 \mathrm{Org} / \mathrm{l}$ during 2012 (Figure 1). The percent composition of zooplankton indicated $27.42 \%$ of rotifers, $18.37 \%$ of cladocers, $36.94 \%$ of copepods and $17.36 \%$ of ostracodes during 2011 (Figure 2). However, the percent composition of zooplankton during 2012 (Figure 3) was rotifers with $25.91 \%$, cladocers with $18.37 \%$, copepods with $37.35 \%$ and ostracodes with $18.11 \%$. Based on percent composition rotifers were observed dominant during 2011 while cladocers were dominant during 2012. 


\section{International Journal of Science and Research (IJSR) \\ ISSN (Online): 2319-7064}

Index Copernicus Value (2013): 6.14 | Impact Factor (2014): 5.611

During the year 2011 (Figure 4), the number of rotifers fluctuated between $12 \mathrm{org} / 1$ to $729 \mathrm{org} / \mathrm{l}$. However, year 2012 (Figure 5) exhibited the rotiferan organisms from 10 $\mathrm{org} / 1$ to $758 \mathrm{org} / \mathrm{l}$. The number of rotifers was noted lower in the month of August during both the years while these were higher in the month of March during both the years. Probably, the number of rotifers decreased during monsoon months and increased during summer months directly interrelate with light penetration and consequently phytoplanktonic growth. Rotiferans are considered as a significant component of the zooplanktons and exhibit a very wide range of morphological variations and adaptations. Among the zooplankton rotifers respond more quickly to the environmental changes and used as a indicator to change in water quality (Gannon and Stemberger 1978). Rotifers are regarded as Bio-indicators of water quality. The present study exhibited monthly variation in the number of rotiferan organisms.

The year 2011 (Figure 4) exhibited cladocers as $16 \mathrm{org} / \mathrm{l}$ (minimum) in the month of June and $466 \mathrm{org} / \mathrm{l}$ in the month of December (maximum). However, year 2012 (Figure 5) exhibited the cladoceron organisms from $22 \mathrm{org} / \mathrm{l}$ to 515 org/l. The number of cladocers were noted lower in the month of June and higher in the month of October during 2012. From the ecological point of view Cladocerans considered to be most important components of zooplankton community. As the Cladocers are prefer to live in clear waters, the diversity revels that the lake water is good environmental condition and less anthropogenic activity Similar results found by Ndebele Murisa (2012).

The number of copepods were varied from 0 org/l (September) to $1078 \mathrm{org} / 1$ (April) during 2011 (Figure 4). The number of copepods were varied from 0 org/l (September)) to $1245 \mathrm{org} / \mathrm{l}$ (March) during 2012 (Figure 5). Copepods are considered as important food item for various kinds of fish, play a key role in the energy transformation at different trophic levels. As a nature of copepod they prefer Eutrophication environment to grow in high number. The species diversity and dominance among Copepoda have been reported by several investigators, Gouder and Joseph, (1961) and Rajashekar et al., (2010). Khan et al., (1986) observed the seasonal change of the copepods in sewage fed ponds of Aligarh.

The number of ostracods ranged between $0 \mathrm{org} / 1$ to $430 \mathrm{org} / \mathrm{l}$ during 2011 (Figure 4) and $0 \mathrm{org} / \mathrm{l}$ and $550 \mathrm{org} / \mathrm{l}$ during 2012 (Figure 5). The minimum number of ostracodes were noted in the months of September during both the years while maximum in the month February during first year and March during second year of the study. The Ostracods are the entomostracans crustaceans having the bivalve carapace enclosing the laterally compressed body. They inhabit all kinds of fresh and marine water.

\section{Conclusion}

The present study concludes that Qualitatively and quanitatiely copepodes were observed dominant which indicates that the water quality of perennial tankis tending towards polltion.

\section{References}

[1] Adoni, A. D., Gulwant, J., Chourasia, S. K., Vaidya, A. K., Yadav, M. and Verma, H. G. (1985). Work book of Limnology, Prabha Publishers, C-10, Gour Nagar, Sagar (India).

[2] Gannon, J. E. and R. E. Stemberger (1978). Zooplankton (especially crustaceans and rotifers) as indicators of water quality. Trans. Am. Micros. Soc, 97: 16-35.

[3] Gouder, B. Y. M. and K. J. Joseph (1961). On the correlation between the natural population of freshwater zooplankton (cladocera, copepoda and rotifera) and some ecological factors. J. Kar. Univ. Sci. 6: 89-96.

[4] Khan, M. A., S. A. Raza, S. A. Iqbal, T. S. Chaghtai, and I. Hussain (1986). Limnochemistry and water quality aspects of the Upper lake of Bhopal during winter season. Ind. J. Appl. Pure Biol. 1(1): 47-50.

[5] Michael, R. G. (1984). Ecological methods for laboratory and field investigations.Tata McGraw Hill publishing Company Ltd. New Delhi. PP. 4-11.

[6] Ndebele M. M. R. (2012). Biological monitoring and pollution assessment of theMukuvisi River, Harare, Zimbabwe. Lakes \& Reservoirs: Research and Management 17: 73-80.

[7] Needham, J. G. and Needham, P. R. (1962).A guide to freshwater biology.Holden Day Ins., San Francisco (USA).PP. 108.

[8] Purushothama, R., H. A. Sayeshwara, Mahesh AnandGuodar and K. Harish Kumar (2011). Physicochemical profile and zooplankton community composition in Brahmana Kalashi tank, Sagara, Karnataka, India. The Ecoscan.5 (1 and 2): 43-48.

[9] Rajashekhar, M., Vijaykumar K. and Zeba Paerveen (2010). Seasonal variations of zooplankton community in freshwater reservoir Gulbarga District, Karnataka, South India. International Journal of Systems Biology,

[10] Rao, S. I. (2005). Zooplankton limnology in the Indian subcontinent, Ukaaz Publication, Hyderabad. PP 209277.

[11] Tonapi, G. T. (1980). Freshwater animals of India an ecological approach. Oxford and IBH Publishing Company, New Delhi. PP 314-315.

[12] Trivedi, R. K. and Goel, P. K. (1984).Chemical and Biological methods for water pollution status. Environmental publication, Karad (India).

[13] Manjare S. A. (2015).

[14] Sachinkumar R. Patil, S. S. Patil and T. V. Sathe (2015). Temporal and Spatial Changes in Zooplankton diversity from Wetlands of Ajara Tahsil, Maharashtra, India. IJISET, 2 (1): 130-143.

[15] Jeje, C. V. and C. K. Fernando (1986).A practical guide of Identification of Nigeria zooplankton, Kainji Lake Institute. pp 89-99. 
International Journal of Science and Research (IJSR)

ISSN (Online): 2319-7064

Index Copernicus Value (2013): 6.14 | Impact Factor (2014): 5.611

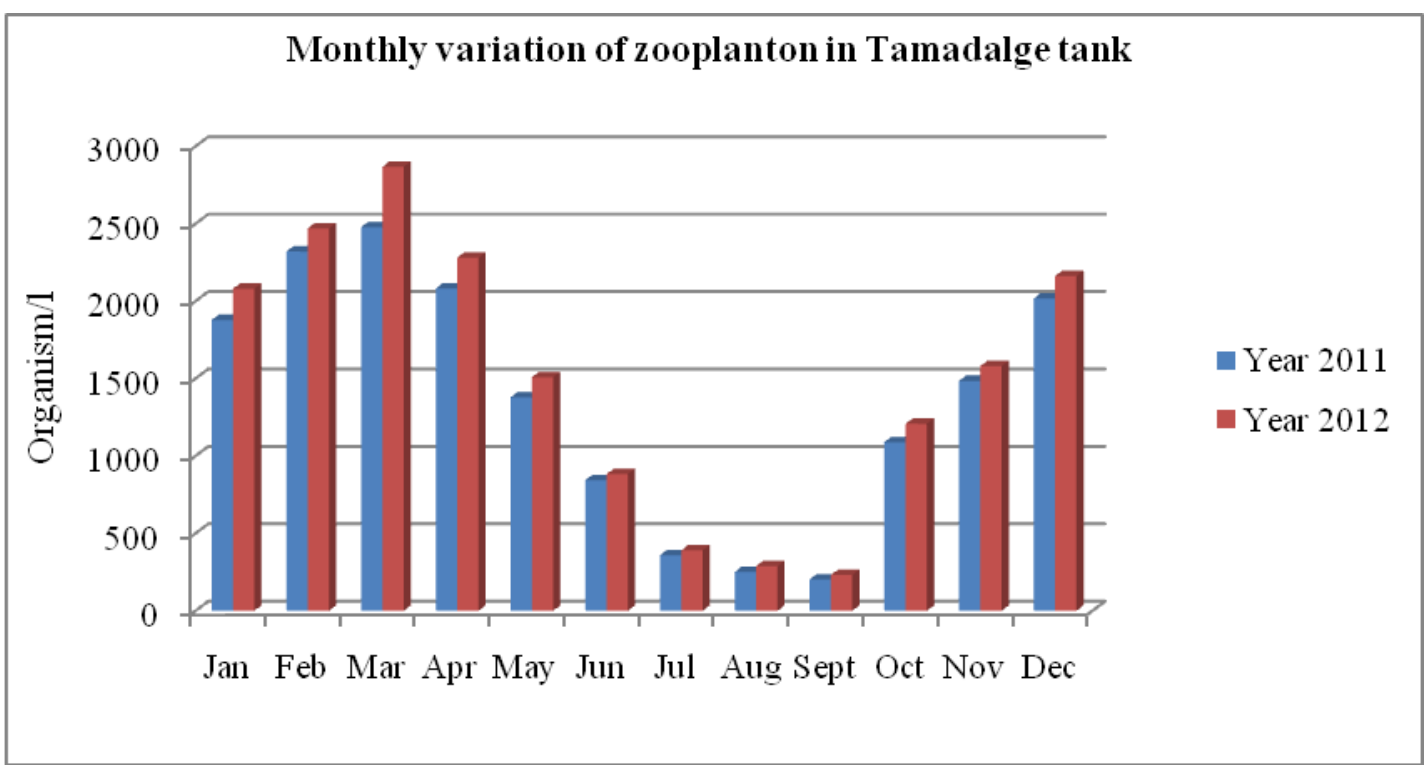

Polpulation dynamics of zooplankton with reference to group sin Tamadalge tank during 2011

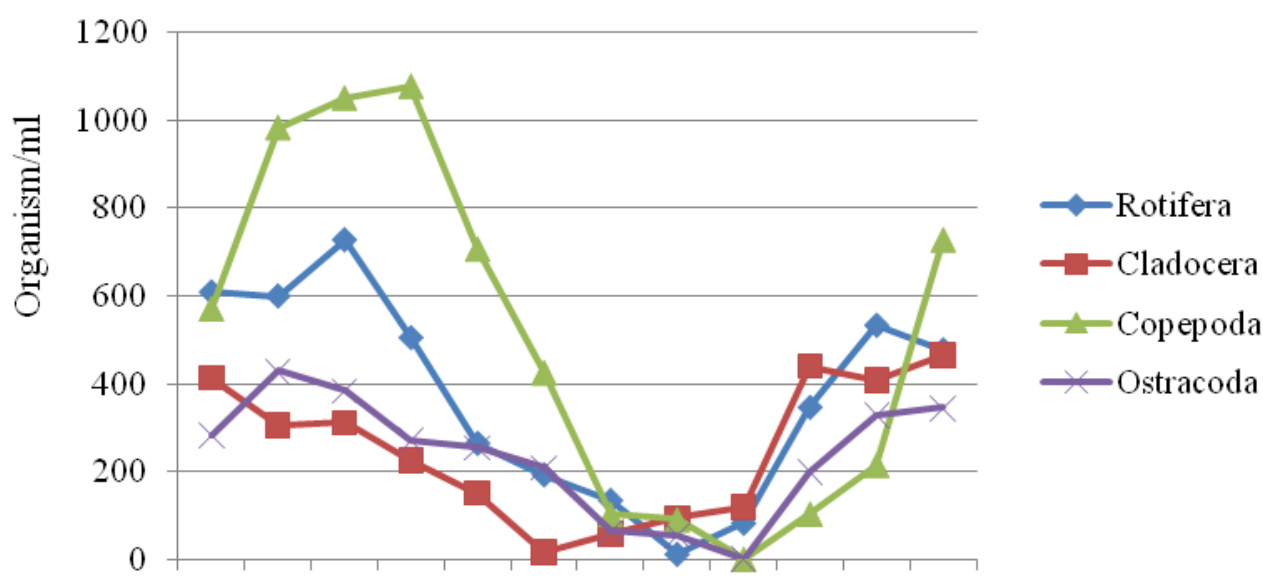

Jan Feb Mar Apr May Jun Jul Aug Sept Oct Nov Dec

Polpulation dynamics of zooplankton with reference to groups in Tamadalge tank during 2012

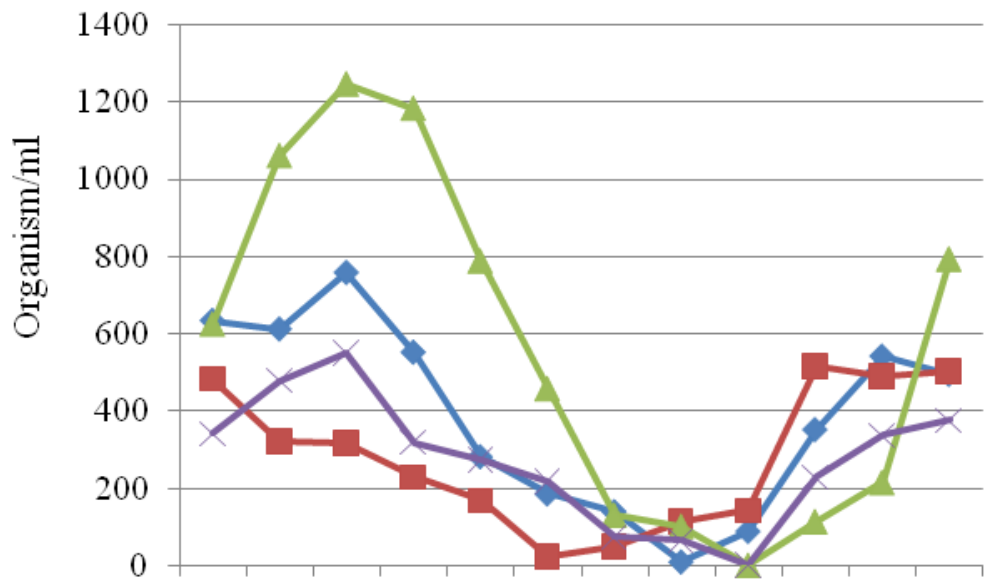

$\sim$ Rotifera

- Cladocera

- Copepoda

$\longleftarrow$ Ostracoda

Jan Feb Mar Apr May Jun Jul Aug Sept Oct Nov Dec

Volume 5 Issue 1, January 2016

www.ijsr.net 
International Journal of Science and Research (IJSR)

ISSN (Online): 2319-7064

Index Copernicus Value (2013): 6.14 | Impact Factor (2014): 5.611

Percent composition of zooplankton in Tamadalge tank during 2011

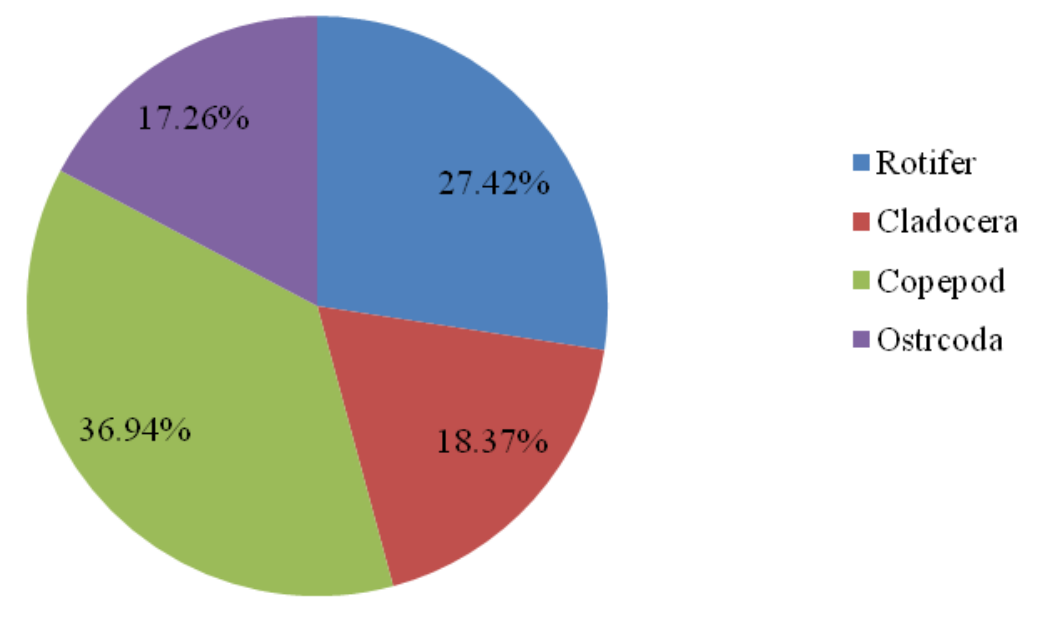

Percent composition of zooplankton in Tamadalge tank during 2012

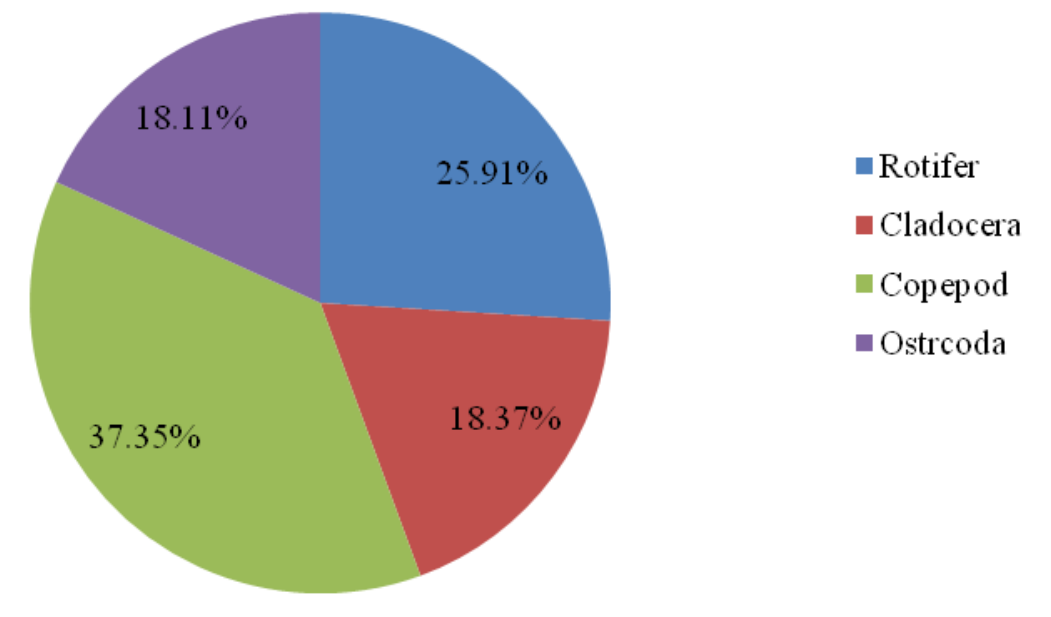

Volume 5 Issue 1, January 2016

www.ijsr.net 